\title{
CORRELATION OF BODY COMPOSITION WITH SPEED AND AGILITY OF CHILDREN AGED 9-10
}

\author{
Mima STANKOVIĆ ${ }^{1}$, Dušan ĐORĐEVIĆ ${ }^{1}$, Milan ZELENOVIĆ ${ }^{1,2}$, Danijel BOŽIĆ ${ }^{1,2}$ \\ ${ }^{1}$ Faculty of Sports and Physical Education, Doctoral Academic Studies, University of Niš, Niš, \\ Republic of Serbia. \\ ${ }^{2}$ Faculty of Physical Education and Sport, University of East Sarajevo, East Sarajevo, Bosnia \\ and Herzegovina. \\ Corresponding author: \\ Milan ZELENOVIĆ \\ Faculty of Physical Education and Sport, University of East Sarajevo, Aleksa Šantić 3, East \\ Sarajevo 71123, Bosnia and Herzegovina. \\ Phone: +38766513469 \\ E-mail: milan.zelenovic@ffvis.ues.rs.ba,milanzeleni13@gmail.com
}

\section{ABSTRACT}

Purpose: Physical growth of children is measured by changes in body size and/or body composition, as well as by changes in motor skills. Motor skills can be affected by many factors, such as genetic predisposition, body composition, socio-economic conditions, and the like. Accordingly, the aim of the research is to determine the correlation between body composition with speed and agility of children aged 9 to 10 years.

Methods: The sample included 40 participants $(29$ boys and 11 girls, $9.47 \pm 0.5$ years). Body height (BH), body weight (BW), body mass index (BMI) and body fat (BF), and basal metabolism (BMR) were determined to assess body composition. The BOT2 subtest was used to assess speed and agility, which includes: Shuttle Run (1SAA), Stepping Sideways over a Balance Beam (2SAA), One-Legged Stationary Hop (3SAA), One-Legged Side Hop (4SAA), Two-Legged Side Hop (5SAA), and Total Speed and Agility (TSAA).

Results: The results of correlation statistics indicated the existence of negative correlations between: height and $3 S A A(r=-.353, p=.026)$; weight and $3 S A A(r=-.422$, $p=.007) ;$ weight and TSAA $(r=-.359, p=.023) ; B M I$ and $3 S A A(r=-.342, p=.031)$; BMI and TSAA $(r=-.333, p=.036) ; B M R$ and 3SAA $(r=-.369, p=.019) ; B M R$ and TSAA $(r=-.363, p=.021)$.

Conclusion: Based on the results obtained in this study, it can be concluded that there is a correlation between body composition and speed and agility. In addition to body composition, a correlation was found between body height and performance of 
Mima STANKOVIĆ, Dušan ĐORĐEVIĆ, Milan ZELENOVIĆ, Danijel BOŽIĆ: CORRELATION OF BODY COMPOSITION ..., 121-130

one-legged stationary hop, as well as between basal metabolism, the one-legged stationary hop test and the overall results achieved in motor skill tests.

Keywords: fat, basal metabolism, motor abilities, OMRON

\section{KORELACIJA MED TELESNO ZGRADBO IN HITROSTJO OZIROMA GIBČNOSTJO PRI OTROCIH, STARIH OD 9 DO 10 LET}

\section{IZVLE ČEK}

Cilj: Telesna rast otrok se meri s spremembami v telesni velikosti in/ali konstituciji ter s spremembami v motoričnih spretnostih. Na slednje lahko vpliva več dejavnikov, od genetske predispozicije in telesne zgradbe, do socialno-ekonomskih razmer in podobno. V skladu s tem je bil cilj naše raziskave ugotoviti, v kakšni korelaciji sta telesna zgradba in hitrost oziroma gibčnost pri otrocih, starih od 9 do 10 let.

Metode: Vzorec je zajemal 40 udeležencev (29 dečkov in 11 deklic, starih $9.47 \pm$ 0.5 let). Pri določanju tipa konstitucije smo upoštevali telesno višino (TV), telesno težo (TT), indeks telesne mase (ITM) in telesno maščobo (TM) ter bazalni metabolizem (BM). Hitrost in gibčnost smo ocenjevali s podtestom BOT-2, ki je vključeval: trajajoči tek sem-tja (1SAA), bočno prestopanje ravnotežnostne gredi (2SAA), enonožne poskoke na mestu (3SAA), enonožne poskoke vstran (4SAA), sonožne poskoke vstran (5SAA) in skupni testni dosežek (TSAA).

Rezultati: Rezultati so nakazali prisotnost negativnih korelacij med: višino in 3SAA $(r=-.353, p=.026)$; težo in 3SAA ( $r=-.422, p=.007)$; težo in TSAA ( $r=-.359, p=.023)$; ITM in 3SAA ( $r=-.342, p=.031)$; ITM in TSAA $(r=-.333, p=.036)$; BM in 3SAA ( $r=-$ .369, $p=.019) ;$ BM in TSAA ( $r=-.363, p=.021)$.

Zaključek: Na podlagi rezultatov študije lahko sklenemo, da obstaja korelacija med telesno zgradbo ter hitrostjo in gibčnostjo. Poleg tega smo zaznali tudi korelacije med telesno višino in izvedbo enonožnih poskokov na mestu ter med bazalnim metabolizmom, izvedbo enonožnih poskokov na mestu in skupnim rezultatom, doseženim na testih motoričnih spretnosti.

Ključne besede: maščoba, bazalni metabolizem, motorične sposobnosti, OMRON 
Mima STANKOVIĆ, Dušan ĐORĐEVIĆ, Milan ZELENOVIĆ, Danijel BOŽIĆ: CORRELATION OF BODY COMPOSITION ..., 121-130

\section{INTRODUCTION}

Physical growth of children is measured by changes in body size and/or body composition as well as changes in motor skills. Physical activity is considered a key factor in the healthy physical and mental development of children (Dencker \& Andersen, 2008; Ortega, Ruiz, Castillo, \& Sjöström, 2008). Regardless of the fact that motor skills during the younger school age (from 7 to 10 years) are not completely differentiated yet, this period is very important in the development of especially basic (general) motor skills. Motor abilities are those anthropological dimensions that are manifested in movement in a way that depends on the type of movement, human potential, and its development in the current moment and conditions (Bala, 2010). Basic motor skills are those that most people possess, and specific ones are those that are created or developed over time, which is most evident in athletes (Nićin, 2000).

Motor abilities can be affected by many factors, such as genetic predisposition, body composition, socio-economic conditions, and the like. By body composition we refer to the composition of the human organism represented by the size and grouping of the existing measurable segments of which it consists (Ugarković, 2001).

Different batteries of tests are used to assess motor abilities, adjusted to the age of the respondents, as well as the level of motor abilities assessed. The standardized battery of tests, most commonly used to assess motor abilities in children, is the BOT-2 (Bruininks-Oseretsky Test) (Bruininks \& Bruininks, 2005).

Research has shown that overweight and obese children have impaired motor skills compared to healthy-weight children, especially in the domain of strength (Đokic \& Međedović, 2013). When the Body Mass Index (BMI) is taken into account, studies unequivocally indicate an association between increased BMI and decreased motor skills in children of different ages (Graf et al., 2004; D'Hondt, Deforche, De Bourdeaudhuij, \& Lenoir, 2009; Đokić \& Međedović, 2013).

Kemp \& Pienaar (2013) conducted research to determine the association between body composition and motor abilities of children in South Africa. Motor abilities were measured using the Bruiniks-Oseretsky Test of Motor Proficiency-2 SF (BOT 2-SF). The obtained results showed a negative correlation between running speed and agility and an increased percentage of fat in children. Gentier et al., (2013) analyzed the differences between fine and gross motor skills in children of normal weight and obese children, aged 7 to 13 years. The BOT-2 test was used to analyze motor abilities. The results showed that obesity is detrimental to performance in all subtests that assess motor speed, which means that obesity also has a bad effect on test results for running speed and agility. Marmeleira, Veiga, Cansado, and Raimundo (2017) conducted research with the aim of determining the association of motor abilities with the body composition of children aged 6 to 10 years. The results showed that children with normal weight achieved better results in all tests compared to their overweight or obese peers. Larsen et al. (2017) conducted an analysis in children from Denmark, ages 8 to 10 , to establish differences in body composition and motor abilities in child athletes and 
Mima STANKOVIĆ, Dušan ĐORĐEVIĆ, Milan ZELENOVIĆ, Danijel BOŽIĆ: CORRELATION OF BODY COMPOSITION ..., 121-130

non-athletes. The results obtained with this test indicated that boys and girls who scored better in speed tests also had better results in relation to body composition.

The aim of this research is to examine the relationship between body composition, speed and agility in children aged 9 to 10 years.

\section{METHODS}

\section{Sample of participants}

In accordance with the set goal, a sample of respondents consisting of third grade pupils of the "Miroslav Antić" elementary school from Niš was selected for this research. The sample included 40 participants (29 boys and 11 girls), aged $9.42 \pm 0.5$ years, with all the respondents being clinically healthy and at the time of measurement displaying no obstructions of the locomotors apparatus that would limit or interfere with the performance. Parents gave their consent for the testing to be performed, and all the examinees voluntarily participated in the testing.

\section{Sample of measuring instruments}

Measuring instruments were used in the research to assess body composition, speed and agility. The characteristics of the sample were assessed: height was measured with a ruler with an accuracy of $0.1 \mathrm{~cm}$; weight, body mass index (BMI), body fat (BF) and basal metabolism (BMR) were measured with the Body Composition Monitor BF511 (OMRON). To assess speed and agility, the BOT-2 test subtest "Running speed and agility BOT-2 test" for motor efficiency of children was applied, which includes the following tests: Shuttle Run (1SAA), Stepping Sideways over a Balance Beam (2SAA), One-Legged Stationary Hop (3SAA), One-Legged Side Hop (4SAA), Two-Legged Side Hop (5SAA) and Total Speed and Agility (TSAA).

\section{Shuttle Run (1SAA)}

The test is performed by the examinee standing at the starting line in the high start position, running 7.62 meters to pick up a ball off the floor and returning to the start. The test is performed twice, the time is measured with an accuracy of 0.1 seconds.

\section{Stepping Sideways over a Balance Beam (2SAA)}

The test is performed by the examinee standing next to the obstacle with hands on hips, then stepping sideways over the obstacle with one foot and then the other, and 
Mima STANKOVIĆ, Dušan ĐORĐEVIĆ, Milan ZELENOVIĆ, Danijel BOŽIĆ: CORRELATION OF BODY COMPOSITION ..., 121-130

returning over the obstacle to the starting position in the same way. The procedure is repeated for 15 seconds. The obtained result is expressed in the number of individual sidesteps.

\section{One-Legged Stationary Hop (3SAA)}

The test is performed by the examinee standing with feet together, hands on hips, bending the weaker leg at the knee so that the lower leg is parallel to the floor. From this starting position, the examinee hops up and down on one leg. The test lasts 15 seconds, and the result is expressed in the number of correctly performed hops.

\section{One-Legged Side Hop (4SAA)}

The test is performed by the examinee standing with both feet together, next to and parallel to the line, with hands on hips, bending the weaker leg at the knee so that the lower leg is parallel to the floor. From this starting position, the examinee hops back and forth over the line. The test lasts 15 seconds, and the result is expressed in the number of correctly performed hops.

\section{Two-Legged Side Hop (5SAA)}

The test is performed by the examinee standing with feet together, next to and parallel to the line, hands on hips, hopping back and forth over the line keeping proper posture with each hop. The test lasts 15 seconds, and the result is expressed in the number of correctly performed hops.

\section{Total Speed and Agility (TSAA)}

Total Speed and Agility is defined as the sum of points scored in each test.

The testing of the children's sample was performed in a gym. The internal temperature in the standardly equipped school hall for physical education was $18-22^{\circ} \mathrm{C}$. All the respondents were tested under the same conditions and reported for measurement and testing in the same order under the guidance of a professor. During the examination, the respondents were in physical education kits. 
Mima STANKOVIĆ, Dušan ĐORĐEVIĆ, Milan ZELENOVIĆ, Danijel BOŽIĆ: CORRELATION OF BODY COMPOSITION ..., 121-130

\section{Data processing}

The processing of data obtained by this research was performed using the statistical program SPSS version 20. For all data obtained by the measurement, the basic central and distribution parameters of descriptive statistics were calculated. Correlation analysis (Pearson's degree of correlation) was used to determine whether there was a relationship between body composition parameters and speed and agility of children aged 9 to 10 years.

\section{RESULTS}

Table 1. Descriptive statistic

\begin{tabular}{|l|c|c|c|c|c|}
\hline & N & Minimum & Maximum & Mean & Std. Deviation \\
\hline Age & 40 & 9 & 10 & 9.47 & .506 \\
\hline Height & 40 & 125.0 & 154.0 & 140.23 & 5.94 \\
\hline Weight & 40 & 27.20 & 57.00 & 38.65 & 8.23 \\
\hline BMI & 40 & 14.40 & 28.50 & 19.58 & 3.50 \\
\hline BF & 40 & 9.20 & 43.20 & 24.55 & 8.68 \\
\hline BMR & 40 & 1087 & 1476 & 1244.23 & 100.57 \\
\hline 1ASS & 40 & 12 & 12 & 12.00 & .000 \\
\hline 2ASS & 40 & 8 & 10 & 9.47 & .560 \\
\hline 3ASS & 40 & 7 & 10 & 8.61 & .728 \\
\hline 4ASS & 40 & 1 & 8 & 4.94 & 1.970 \\
\hline 5ASS & 40 & 5 & 9 & 7.14 & .867 \\
\hline TSAA & 40 & 33 & 47 & 42.17 & 2.962 \\
\hline
\end{tabular}

$N$ sample size, BMI body mass index, BF body fat, BMR basal metabolism, 1SAA Shuttle Run, 2SAA Stepping Sideways over a Balance Beam, 3SAA One-Legged Stationary Hop, 4SAA OneLegged Side Hop, 5SAA Two-Legged Side Hop, TSAA Total Speed and Agility

Table 1 shows basic descriptive parameters: sample size $(\mathrm{N})$, minimal result, maximum result, arithmetic mean (Mean), and standard deviation (Std. Deviation) for each variable separately. On the $1 \mathrm{ASS}$ test each respondent achieved maximum result, that is, they scored the highest number of points (Mean 12; Std. Deviation .000) possible. Consequently, the correlation analysis wasn't performed. 
Mima STANKOVIĆ, Dušan ĐORĐEVIĆ, Milan ZELENOVIĆ, Danijel BOŽIĆ: CORRELATION OF BODY COMPOSITION ..., 121-130

Table 2. Correlation analysis (Pearson's correlation coefficient)

\begin{tabular}{|l|c|c|c|c|c|}
\hline & 2SAA & 3SAA & 4SAA & 5SAA & TSAA \\
\hline Height & -0.143 & $-.353^{*}$ & -0.115 & -0.217 & -0.271 \\
\hline Weight & -0.254 & $-.422^{* *}$ & -0.223 & -0.136 & $-.359^{*}$ \\
\hline BMI & -0.227 & $-.342 *$ & -0.247 & -0.087 & $-.333^{*}$ \\
\hline BF & -0.207 & -0.304 & -0.199 & -0.065 & -0.279 \\
\hline BMR & -0.17 & $-.369 *$ & -0.272 & -0.143 & $-.363 *$ \\
\hline
\end{tabular}

BMI body mass index, BF body fat, BMR basal metabolism, 2SAA Stepping Sideways over a Balance Beam, 3SAA One-Legged Stationary Hop, 4SAA One-Legged Side Hop, 5SAA TwoLegged Side Hop, TSAA Total Speed and Agility

$* p<0.05$

Based on the results of the correlation analysis shown in Table 2, between the parameters of body composition and motor abilities of children aged 9 to 10 years, the existence of statistically significant correlations was determined. The results of correlation statistics indicated the existence of the following correlations:

- Negative correlation $(\mathrm{r}=-.353)$ between height and 3SAA parameters, with statistical significance $\mathrm{p}=.026$;

- Negative correlation $(\mathrm{r}=-.422)$ between weight and 3SAA parameters, with statistical significance $\mathrm{p}=.007$;

- Negative correlation $(\mathrm{r}=-.359)$ between weight and TSAA parameters, with statistical significance $\mathrm{p}=.023$;

- Negative correlation $(\mathrm{r}=-.342)$ between BMI and 3SAA parameters, with statistical significance $\mathrm{p}=.031$;

- Negative correlation $(\mathrm{r}=-.333)$ between BMI and TSAA parameters, with statistical significance $\mathrm{p}=.036$;

- Negative correlation $(\mathrm{r}=-.369)$ between BMR and 3SAA parameters, with statistical significance $\mathrm{p}=.019$;

- Negative correlation $(\mathrm{r}=-.363)$ between the parameters of basal metabolism BMR and TSAA, with statistical significance $\mathrm{p}=.021$.

\section{DISCUSSION}

Research studies analyzed for the purposes of this paper (Kemp \& Pienaar, 2013; Gentier et al., 2013; Marmeleira et al., 2017) did not relate the height of the respondents with the success in performing motor skill tests used to determine running speed and agility. This negative correlation obtained in this study can be explained by the fact that while children of that age very often grow abruptly, the muscular strength and body 
Mima STANKOVIĆ, Dušan ĐORĐEVIĆ, Milan ZELENOVIĆ, Danijel BOŽIĆ: CORRELATION OF BODY COMPOSITION ..., 121-130

growth may not develop at similar rates, and, as it is already known, explosive strength is one of the essential parameters of agility and running speed.

Previous research has shown a negative correlation between body weight of the respondents, regardless of gender, and success in performing motor tests for speed running and agility. Research conducted in Africa showed a negative association in children with an average age of 6.84 years (Kemp \& Pienaar, 2013), who were slightly younger than the respondents in this study where there were statistically significant negative correlations between the body weight of the respondents and motor skill tests results, as well as between BMI and motor skill tests results. Specifically, the One-Legged Stationary Hop test and the Overall Motor Skills test results were negatively correlated with BMI values and weight of the respondents.

Previous research analyzed in this paper (Baine, Gorman, Kern, Hunt, Denny, \& Farry, 2009; Gentier et al., 2013; Chowdhury, Wrotniak, \& Ghosh, 2016; Marmeleira et al., 2017) investigated the influence of increased body weight and BMI on the performance of motor skill tests for running speed and agility, which were part of the BOT-2 test. Such a correlation between agility and increased body weight may result from the fact that most children with increased body weight are less physically active, so their muscles are less developed. As previously explained, muscle development is directly related to muscle strength, which affects the speed of running and the speed of change of direction. Moreover, the results obtained in this study show that BMI and weight are negatively correlated with the overall results of motor skill tests, which coincides with the results of research that confirmed that obese children achieve poorer results on motor tests (Baine et al., 2009; Đokić \& Međedović, 2013; Chowdhury et al., 2016). Such results assume that children with increased body weight and body mass index (BMI) are motor weaker than their peers with normal body weight. Obesity in children at that age usually results from insufficient physical activity.

In addition to the analysis of body composition, the correlation of BMR with tests of motor abilities for agility and running speed was analyzed. The study showed that BMR is negatively correlated with 3SAA and TSAA. The dominant factors that affect the value of basal metabolism are the size of the organism, age and sex. As we have seen, BMR directly depends on body surface area and cell mass. Obese people have a larger body surface area and a higher cell mass compared to children of normal weight, so the rate of metabolism in obese people is higher. Based on the above, we can conclude that BMR is directly proportional to weight and BMI, thus explaining the negative correlation between BMR and the One-Legged Side Hop test (3SAA) and the overall results achieved (TSAA) on the motor skill test.

The fact that there is no correlation between the body composition and other tests used to assess running speed and agility, excepting the One-Legged Stationary Hop tests can be explained by the small number of examinees as well as by the motivation the examinees themselves had during the testing. 
Mima STANKOVIĆ, Dušan ĐORĐEVIĆ, Milan ZELENOVIĆ, Danijel BOŽIĆ: CORRELATION OF BODY COMPOSITION ..., 121-130

\section{CONCLUSION}

Based on the results obtained in this study it can be concluded that there is a correlation between body composition and speed and agility. In addition to the physical composition, a correlation was also found between body height and the performance of the One-Legged Stationary Hop tests, as well as between basal metabolism, One-Legged Stationary Hop tests, and the overall results achieved on motor skill tests.

The limitation of this study is the small number of participants, so we suggest a larger sample for future research and a separate treatment of boys and girls.

The obtained results are important for further work, because they proved a correlation between body composition, speed and agility; but in future research a larger sample of respondents of the same age should be examined. Also, the differences depending on the gender of the respondents could be taken into account.

\section{REFERENCES}

Baine, B., Gorman, D., Kern, C. J., Hunt, B. S., Denny, S. G., \& Farris, W. J. (2009). Relationship between Body Mass Index and Motor Skills of Children. Exhibit Hall RC Poster Sessions (Tampa Convention Center).

Bala, G. (2010). Metodologija kineziometrijskih istraživanja sa posebnim osvrtom na motorička merenja [Methodology of kinesiometric research with special emphasis on measuring motor skills]. Novi Sad, Srbija: Fakultet sporta i fizičkog vaspitanja Univerziteta u Novom Sadu, Old commerce d.o.o.

Bruininks, R. H., \& Bruininks, B. D. (2005). Bruininks-Oseretsky Test of Motor competence (BOT-2; 2nd ed.). Crowley, TX: AGS.

Chowdhury, S. D., Wrotniak, B. H., \& Ghosh, T. (2016). Association between Body Mass Index and Motor Competence in Santal Children of Purulia District, India. Journal of Motor Behavior, 49(3), 349-354. https://doi.org/10.1080/00222895.2016.1219308

Dencker, M., \& Andersen, L. B. (2008). Health-related aspects of objectively measured daily physical activity in children. Journal of Sports Medicine, 28(3), 133-144. https:// doi.org/10.1111/j.1475-097X.2008.00788.x

D’Hondt, E., Deforche, B., De Bourdeaudhuij, I., \& Lenoir, M. (2009). Relationship between motor skill and body mass index in 5- to 10-year-old children. Adapted Physical Activity Quarterly, 26(1), 21-37. https://doi.org/10.1123/apaq.26.1.21

Đokić, Z., \& Međedović, B. (2013). Povezanost prekomerne uhranjenosti i gojaznosti sa motoričkim sposobnostima dece od 9-12 godina [Relationship between overwight, obesity and the motor abilities of 9-12 year old school children]. Fizička kultura, 67(2), 91102. Retrieved from https://scindeks.ceon.rs/article.aspx?artid=0350-38281302091D

Gentier, I., D'Hondt, E., Shultz, S., Deforche, B., Augustijn, M., Hoorne, S., ... Lenoir, M. (2013). Fine and gross motor skills differ between healthy-weight and obese children. Research in Developmental Disabilities, 34(11), 4043-4051. https://doi. org/10.1016/j.ridd.2013.08.040

Graf, C., Koch, B., Kretschmann-Kandel, E., Falkowski, G., Christ, H., Coburger, S., ... Dordel, S. (2004). Correlation between BMI, leisure habits and motor abilities in 
Mima STANKOVIĆ, Dušan ĐORĐEVIĆ, Milan ZELENOVIĆ, Danijel BOŽIĆ: CORRELATION OF BODY COMPOSITION ..., 121-130

childhood (CHILT-Project). International Journal of Obesity, 28(1), 22-26. https://doi. org/10.1038/sj.ijo.0802428

Kemp, C., \& Pienaar, A. (2013). Relationship between the body composition and motor and physical competence of Grade 1 learners in South Africa. The journal of sports medicine and physical fitness. 53(6), 635-643.

Larsen, M., Nielsen, C., Ørntoft, C., Randers, M., Manniche, V., Hansen, L., ... Krustrup, P. (2017). Physical fitness and body composition in 8-10-year-old Danish children are associated with sports club participation. Journal of Strength and Conditioning Research, 31(12), 3425-3434. https://doi.org/10.1519/JSC.0000000000001952

Marmeleira, J., Veiga, G., Cansado, H., \& Raimundo, A. (2017). Relationship between motor proficiency and body composition in 6- to 10-year-old children. Journal of Pediatrics and Child Health. 53(4), 348-354. https://doi.org/10.1111/jpc.13446

Nićin, Đ. (2000). Antropomotorika-teorija [Anthropomotorics - Theory]. Novi Sad, Srbija: Fakultet fizičke kulture.

Ortega, F. B., Ruiz, J. R., Castillo, M. J., \& Sjöström, M. (2008). Physical fitness in childhood and adolescence: a powerful marker of health. International Journal of Obesity, 32, 1-11. https://doi.org/10.1038/sj.ijo.0803774

Ugarković, D. (2001). Osnovi sportske medicine [The Basics of Sports Medicine]. Beograd, Srbija: Viša škola za sportske trenere. 